\title{
The COVID-19 pandemic: theoretical scenarios of its socioeconomic impacts in Latin America and the Caribbean
}

\author{
A pandemia do Covid-19: cenários teóricos de seus impactos \\ socioeconômicos na América Latina e no Caribe
}

\author{
CINTYA LANCHIMBA* \\ ANDREA BONILLA-BOLAÑOS** \\ JUAN PABLO DÍAZ-SÁNCHEZ***
}

\begin{abstract}
RESUMO: Este artigo apresenta alguns cenários teóricos dos impactos socioeconômicos causados pela pandemia da Covid-19 na América Latina e no Caribe (ALC). Para isso, após uma breve revisão da literatura de pandemias anteriores, usamos a teoria macro e microeconômica, juntamente com dados agregados, a fim de fornecer implicações esperadas da pandemia de Covid-19 para a região da ALC. No nível macroeconômico, explicamos como o choque de Covid-19 está causando uma redução na oferta agregada e na demanda agregada, mergulhando a região em uma recessão, e por que essa recessão é perigosamente prejudicial para as economias da ALC. No nível micro, descrevemos por que algumas empresas se adaptariam para permanecer no mercado ou até para crescer; por outro lado, alguns deles sairiam do mercado no curto prazo. Para os consumidores, o impacto dessa crise sanitária está relacionado à mudança nas preferências e nas relações dos familiares devido a quarentenas prolongadas.

PALAVRAS-CHAVE: América Latina e Caribe; Covid-19; implicações socioeconômicas.
\end{abstract}

ABSTRACT: This paper provides some theoretical scenarios the socioeconomic impacts caused by the COVID-19 pandemic for the Latin America and the Caribbean (LAC). To do so,

\footnotetext{
* Associate Professor. IDEA Research Group, Department of Quantitative Economics, Escuela Politécnica Nacional, Quito, Ecuador \& Institut de Recherche en Gestion et Economie, Université de Savoie Mont Blanc (IREGE/IAE Savoie Mont Blanc), Annecy, France. E-mail: cintya.lanchimba@epn.edu.ec. Orcid: http://orcid.org/0000-0003-2837-9107.

* Assistant Professor. IDEA Research Group, Department of Quantitative Economics, Escuela Politécnica Nacional, Quito, Ecuador \&. CNRS, GATE Lyon-St Etienne, UMR n 5824 Université de Lyon, France. E-mail: andrea.bonilla@epn.edu.ec. Orcid: http://orcid.org/0000-0001-5191-8522.

*** Associate Professor. IDEA Research Group. Department of Quantitative Economics, Escuela Politécnica Nacional, Quito, Ecuador. E-mail: juan.diaz@epn.edu.ec. Orcid: http://orcid.org/0000-00017131-7994. Submitted: 2/June/2020; Approved: 17/June/2020.
} 
after a brief literature review of previous pandemics, we use the macro and microeconomic theory, together with aggregated data, in order to provide expected implications of the COVID-19 pandemic for the LAC region. At a macroeconomic level, we explain how the COVID-19 shock is causing both aggregate supply and aggregate demand to reduce so plunging the region into a recession and why such a recession is dangerously harmful for the LAC economies. At a micro level, we describe why some enterprises would adapt to remain in the market or even growth; by contrast, some of them would leave the market in the short term. For the consumers, the impact of this sanitary crisis is related to the change in their preferences and household members' relations due to extended quarantines.

KEYWORDS: Latin America and the Caribbean; COVID-19; socioeconomic implications. JEL Classification: D10; D20; D84; E10; F22.

\section{INTRODUCTION}

The recently emerged SARS-CoV-2, that caused the so-called COVID-19 outbreak disease, was firstly reported from Wuhan, China, at late December 2019 (WHO, 2020a). Since then, according the Johns Hopkins University, by mid-May 2020, there are more than 4380000 reported cases of COVID-19 in 188 countries. The propagation of the virus is quite fast. It only took 30 days to expand from Hubei, the province in which Wuhan is located, to the rest of Mainland China (Novel Coronavirus Pneumonia Emergency Response Epidemiology Team, 2020). Experts indicate that COVID-19 is an acute resolved disease but it can also be deadly, with a $2 \%$ case fatality rate (Xu et al., 2020).

The effects of this pandemic are all over the world in the majority of economic sectors and countries. In that venue, it is expected that developing economies have to face more challenging scenarios compared to developed economies due to the fragility of their economic and health systems.

In this context, this study seeks to dilucidated the economic implications of the COVID-19 pandemic on Latin America and the Caribbean (LAC) region. More precisely, this article indents to provide some theoretical clues about the macroeconomic impacts and the microeconomic effects caused by the COVID-19 pandemic on the LAC region. The discussion will be held in two stages. The macroeconomic perspective is considered first by analyzing both the structural economic conditions of the LAC countries and their capacity of reaction through macroeconomic policy. The microeconomic effects are discussed next to understand the consequences of social isolation measures for both firms and consumers.

On the macroeconomic side, the overall expected impacts are detailed by using the theoretical predictions of an Aggregate Demand - Aggregate Supply (AD-AS) apparatus. The COVID-19 pandemic is analyzed as both a demand and a supply perturbation. The impacts on the LAC economies are case specific and very likely to depend on: (i) the severity of the containment measures, (ii) the structural economic conditions of countries including its role on international trade, (iii) the economic policies implemented by each country, and (iv) the implemented social 
aids. This paper analyses the LAC region by focusing on the connection between (ii) and (iii): the structural economic conditions of LAC countries will determine the extent to which they can react and implement economic policies.

On the microeconomic side, an overview about the survival of firms is presented. Specifically, we analyze two representative economic sectors. One of them shows those who are getting advantage of sanitary crisis (i.e., food sector), and the other represents the firms with an uncertainly future (i.e., tourism sector). Moreover, the change in the consumers preferences are also analyzed as well as the social implication such as migration, sanitary structure, and gender perspectives within the region.

The discussion of the first stage leads to conclude that the macroeconomic effects of the COVID-19 pandemic for LAC countries are very similar for all the economies of the region but they magnitude is highly dependent on the pre-COVID-19 economic condition of each LAC country as well as to their economic structure. The most vulnerable LAC economies appears to be Venezuela, Ecuador, and Argentina.

Regarding the second stage, the microeconomic impact for LAC countries could be divided into consequences for firms and households. Regarding firms, some of them would have to adapt their operations and channels of commercialization to stay in the market or even grow. In contrast, other firms would leave the market in the short-run. For households, the impact of this sanitary crisis would affect their consumption preferences due to closeness of non-essential business (mandatory quarantines) or variations of income. Further, some social implications can be derived such as those related to migration movements, flow of remittances and gender violence at household level.

The remainder of the article is organized as follows: a review of the socioeconomic effects of previous pandemics in the world is presented in the second section. The third section sets the case of study, the LAC region. The fourth section discusses both the macro and microeconomic implications of the COVID-19 pandemic for the LAC region. The discussion about the economic implication are combines data and theoretical expectations. Finally, the fifth section concludes by summarizing the main COVID-19 implications and suggesting some policy recommendations.

\section{LITERATURE REVIEW ABOUT PANDEMICS}

Pandemics have been with humanity throughout our history. Some of them have had severe consequences on demographics, the economy of the nations and human societies (Signoli, 2012). In fact, starting from the growth of human settlements as well as the commercial exchange between peoples, diseases seem to happen with greater frequency. Spyrou et al. (2016) argue that the lack of hygienic or even something as simple as not having clean water would have increased the probability of viruses spread. Table 1 summarizes some of the most dangerous plagues that scourged humanity. 
Table 1: Important pandemics data

\begin{tabular}{|c|c|c|c|c|c|c|c|}
\hline & $\begin{array}{l}\text { Plague of } \\
\text { Justinian }\end{array}$ & Black Death & Smallpox & $\begin{array}{l}\text { Great Plague } \\
\text { of Marseille }\end{array}$ & $\begin{array}{l}\text { The } \\
\text { Spanish } \\
\text { Flu }\end{array}$ & $\begin{array}{l}\text { Severe acute } \\
\text { respiratory } \\
\text { syndrome }\end{array}$ & COVID-19 \\
\hline Period & $\begin{array}{c}\text { 6th and 8th } \\
\text { centuries } \\
\text { AD }\end{array}$ & $\begin{array}{l}\text { (i) from mid-14th } \\
\text { to mid-18th and } \\
\text { (ii) 19th century }\end{array}$ & 1520 & 1720-1722 & $\begin{array}{c}\text { January } \\
1918 \text { to } \\
\text { December } \\
1920\end{array}$ & 2002 & ongoing \\
\hline Place & $\begin{array}{l}\text { Eastern } \\
\text { Roman } \\
\text { Empire }\end{array}$ & $\begin{array}{c}\text { (i) Europe (ii) } \\
\text { China }\end{array}$ & America & $\begin{array}{l}\text { Outbreaks } \\
\text { across } \\
\text { Europe }\end{array}$ & Worldwide & China & Worldwide \\
\hline Deaths & $\begin{array}{l}20 \% \text { of the } \\
\text { worldwide } \\
\text { population }\end{array}$ & $\begin{array}{l}50 \% \text { of the } \\
\text { European } \\
\text { population }\end{array}$ & $\begin{array}{c}2 \text { to } 3.5 \\
\text { million } \\
\text { indigenous } \\
\text { people died }\end{array}$ & $\begin{array}{l}40 \text { thousand } \\
\text { deaths in } \\
\text { Europe }\end{array}$ & $\begin{array}{l}50 \text { million } \\
\text { deaths } \\
\text { worldwide }\end{array}$ & $\begin{array}{l}\text { Average } \\
\text { worldwide } \\
\text { mortality } \\
\text { rate of } \\
\text { around } 13 \%\end{array}$ & $\begin{array}{c}\text { Average } \\
\text { worldwide } \\
\text { mortality rate } \\
\text { of around } \\
5 \%\end{array}$ \\
\hline
\end{tabular}

Source: Signoli (2012), Spyrou et al. (2016), Eichelberger (2007), Smith (2006), Lee \& McKibbin (2004), World Health Organization (2020).

From the pandemics, described in Table 1, we can observe that they can spot in any place of the world and that they affect both the health and the economic fields. Clearly, they change the composition of population due to the millions of deaths that they caused. Thus, the challenge for governments is twofold: ensuring an efficient enough health system for their citizens and, guaranteeing economic stability. For instance, in the case of COVID-19 pandemic, the number of deaths is increasing in countries with a high proportion of elderly, forcing governments around the world to take drastic measures such as the confinement of its population to prevent the massive spread of the virus. Although these measures have had a positive impact on the containment of the virus, the macroeconomic and microeconomic effects on the world economy have been devastating. For instance, tourism activities, air transport sector, stock markets and other productive activities, which are not linked to basic consumer goods, are among the severely affected industries. Economic analysts around the world agree that the main consequence of COVID-19 on the economy is a strong economic recession worldwide (BBC, 2020a). Notwithstanding, developed countries are better prepared to face crisis, for instance, countries like France or Spain ensure the economic survival of their population through monetary transfers from the government to the population (Conseil de l'Union européenne, n.d.). However, developing economies, as Ecuador, face a more challenging situation because the pandemic not only surpasses its poor health system, but also its economic situation is aggravated by the deep oil price fall which is its main source of funding. In this order of ideas, LAC case is discussed next.

\section{THE CASE OF STUDY}

LAC is a region with $641.4 \mathrm{M}$ inhabitants spanned for $22 \mathrm{M} \mathrm{km}^{2}$ and laying in the Western hemisphere. According to the World Bank (2020), this region was 
composed in 2018 by $25 \%$ of young ( $0-14$ years old), $67 \%$ of middle age (15-64 y.o.), and $8 \%$ of elderly (equal or higher than 65 y.o.) population. Politically speaking, the LAC region is composed by 58 heterogeneous countries and territories. In economic terms, the GDP of the region is 5.801 trillion USD in 2018 (The World Bank, 2020b).

The first confirmed case of COVID-19 in LAC was reported in São Paulo (Brazil) on February 25th, 2020. It corresponded to a Brazilian 61-year-old man who had travelled to Lombardy between February 9th and 20th. One month after the first reported case, all LAC countries had COVID-19 confirmed cases and each of them adopted different strategies in order to face the pandemic (see Appendix 1). Nevertheless, LAC has the advantage of the lag in time of the first reported case compared to, for instance, Europe, so that governments may have had, more time to prepare contingency plans (BBC, 2020b).

\section{PERSPECTIVES OF THE IMPLICATIONS IN LATIN AMERICA}

\section{Macroeconomic perspectives}

The COVID-19's pandemic necessarily implies a global economic recession. The very nature of any containment strategy reduces economic activity so that aggregate supply (AS) and aggregate demand (AD) fall. Indeed, theoretically, COVID-19 may be analyzed as both a supply and a demand shock: (i) AS is perturbed by the disruption in global supply chains, the reduction of labor supply caused by quarantine and social distancing; (ii) $\mathrm{AD}$ is disrupted not only because of the fall in consumption of durable goods (cars, household appliances, consumer electronics, etc.) and services (restaurants, tourism, etc.) caused by the lockdown, but also because the uncertainty about the disease causes households to increase precautionary savings so reducing consumption, some non-permanent or informal workers, as well as renters, lose income so reducing consumption, and, due to the uncertainty and the lack of liquidity, some firms stop investing.

As the development of a SARS-CoV-2 vaccine is expected to take several months (Chen, Strych, Hotez, \& Bottazzi, 2020; Prompetchara, Ketloy, \& Palaga, 2020 ), so prolonging the necessity of containment measures that stop or slow down several economic sectors, the $\mathrm{AD}$ disruption is very likely to involve a feedback loop into AS. Indeed, firms and business facing lower demand will produce and sell less and might be forced to file for bankruptcies causing jobs destruction. The loop will continue with the spreading effect to the AD: new unemployed people will consume less, and so on. In general, the multiplier effect of consumption will be significantly negative and will be worsen by the lack of private investment.

Although the overall theoretical scenario implies negative shocks in both AS and $\mathrm{AD}$, not all economic sector will face negative supply and demand shocks. 
On the supply side, some industries are selling more: those whose products are needed to contain COVID-19 (disinfection products, medical protective equipment as mask and glasses, special clothes), the ones that produce basic consumption products (food and medicines) and the ones that provide entertainment and internet services. Notwithstanding, at an aggregate level, supply is expected to fall: most industries stopped its activities: tourism, fashion, transportation, restaurants, bars, among others (a further micro analysis by economic sector is presented next). On the demand side, even if aggregate household consumption and investment fall, public spending must increase to finance the COVID-19 containment strategies and social help. So, the AD shock might be less severe: while aggregate consumption and aggregate investment are very likely to fall, public demand significantly increases so that the net effect on $\mathrm{AD}$ is less evident.

At a monetary level, inflation is expected to accelerate because of the AD-AS negative shocks. Moreover, liquidity problems are emerging because of the economic activity paralysis, as well as, disruptions in payment chains, and losses of profitability and wealth.

These short run expected disruptions on AS and AD will transcend to medium- and long-run economic consequences, i.e.,, business bankruptcies, lower economic growth, less integration in value chains, deterioration of productive capacities and of human capital. The magnitude of the impacts in time will be different for each country and will depend on: (i) the severity of the containment measures, (ii) the structural economic conditions of countries including its role on international trade, (iii) the economic policies implemented by each country, and (iv) the implemented social aids. Regarding the LAC region, we will dilucidated about the connection between (ii) and (iii): the structural economic conditions of LAC countries will determine the extent to which they can react and implement economic policies (ECLAC, 2020).

\section{LAC countries' structural economic conditions}

It is necessary to remark that the global economic performance was already weak before the COVID-19 pandemic. According to CEPAL (2020), the average world economic growth rate, during the period 2011-2019, was $2.8 \%$ which is less than the 3.4\% registered during the 1997-2006 (2008 crisis excluded). Regarding LAC, its average economic growth, during the period 2011-2018 was only $1.7 \%$ while, during $1997-2006$, it was $3 \%$, according to the World Bank data (see Table 2 for a disaggregation). Moreover, in 2019 the word economy grew only $2.5 \%$, its worst performance since 2009 . So, the pandemic worsened an already started situation of global recession. 


\begin{tabular}{|c|c|c|}
\hline Country Name & $(1997-2006)$ & $(2011-2018)$ \\
\hline Argentina & 2.7 & 0.7 \\
\hline Antigua and Barbuda & 4.8 & 3.1 \\
\hline Bolivia & 3.3 & 5.0 \\
\hline Brazil & 2.7 & 0.6 \\
\hline Chile & 4.6 & 3.3 \\
\hline Colombia & 2.8 & 3.7 \\
\hline Costa Rica & 4.7 & 3.6 \\
\hline Caribbean small states & 4.0 & 0.5 \\
\hline Cuba & 5.2 & 2.3 \\
\hline Dominica & 2.0 & -0.3 \\
\hline Dominican Republic & 5.3 & 5.4 \\
\hline Ecuador & 3.3 & 3.1 \\
\hline Guyana & 1.4 & 4.0 \\
\hline Honduras & 4.5 & 3.8 \\
\hline Haiti & 0.8 & 2.6 \\
\hline Jamaica & 1.1 & 0.9 \\
\hline LAC (excluding high income) & 2.9 & 1.7 \\
\hline LAC & 3.0 & 1.7 \\
\hline Mexico & 3.1 & 2.7 \\
\hline Nicaragua & 3.9 & 4.1 \\
\hline Panama & 5.1 & 6.6 \\
\hline Peru & 3.9 & 4.3 \\
\hline Puerto Rico & 3.2 & -1.5 \\
\hline Paraguay & 1.5 & 4.1 \\
\hline El Salvador & 2.1 & 2.5 \\
\hline Suriname & 4.1 & 0.8 \\
\hline Uruguay & 1.5 & 2.9 \\
\hline Venezuela, RB & 3.0 & 1.8 \\
\hline World & 3.4 & 2.9 \\
\hline
\end{tabular}

Source: The World Bank Data. NY.GDP.MKTP.KD.ZG Indicator.

As for world trade, it was also already slowing down before the COVID-19 outbreak. In 2019, the volume of world merchandise trade fell $0.4 \%$, its first decline since the 2008-2009 global financial crisis (CEPAL, 2020). The EEUU-China commercial dispute, started in 2018, and the highly interconnected global value chains causes all economics to suffer. LAC countries are particularly vulnerable to these disturbances because they are characterized by being commodities producers and the commodity prices are very volatile (see Figure 1). Moreover, since the 2000s, 
the global demand for commodities is largely determined by China (Gallagher \& Porzecanski, 2009) whose economy not only has started to slow down since 2011 (according to the World Bank data, the 9.6\% Chinese annual growth of 2011 systematically declined and reached a $6.6 \%$ in 2018), but also was the first to adopt the lockdown because of being the origin of the COVID-19 pandemic. As the global demand for commodities reduces, commodities prices fall, and LAC economies suffer.

Figure 1: Evolution of All Commodity Price Index (monthly data: 1992-2020)

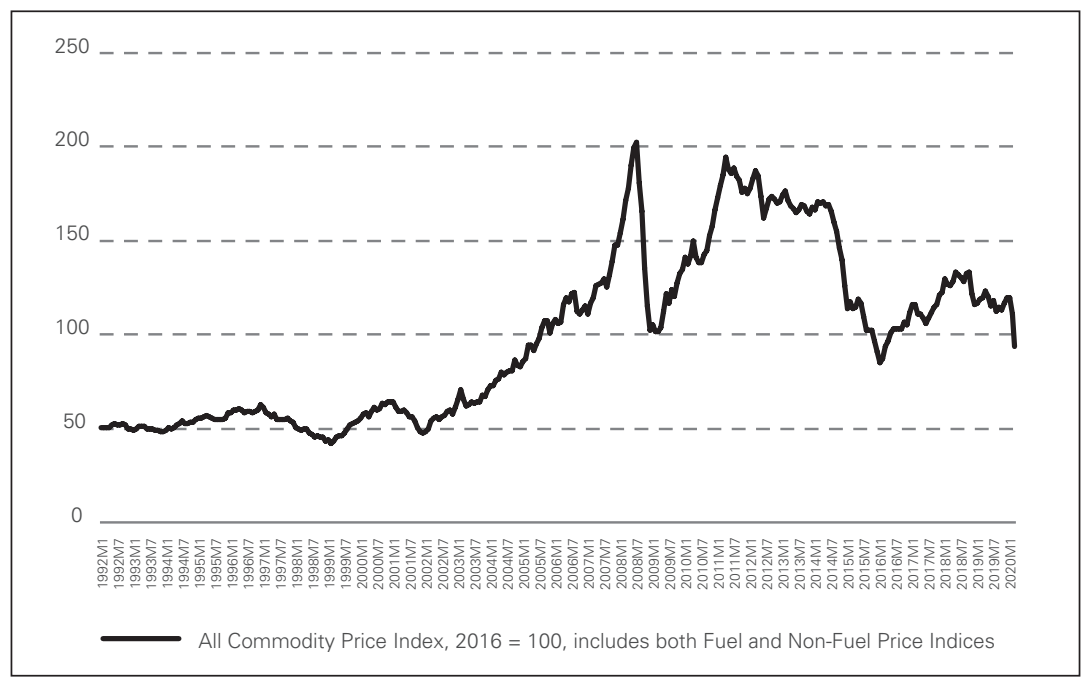

Source: IMF Data (https://www.imf.org/en/Research/commodity-prices).

In fact, according to CEPAL (2020), COVID-19 affects the region through five external transmission channels: (i) the decrease in the economic activity of its main trading partners, (ii) the deterioration of commodity prices, (iii) the disruption of global value chains, (iv) the lower demand for tourism services, (v) the intensified risk aversion and worsening global financial conditions. However, only the second channel is specific for the region, the other four channels of COVID-19's affectation are common to most of world economies.

The commodity which price have deteriorated the most is oil. The price of U.S. West Texas Intermediate (WTI) crude, reference for the price of LAC oil, fell from $\$ 46.78$ on March 4th to $-\$ 37.63$ on April 20th, an unprecedented drop. The dramatic drop in WTI is attributed to the sharp drop in demand caused by the reduced economic activity due to COVID-19 together to the excess supply in the market: the difficulties and cost of storing oil surplus production is such that producers must "pay consumers to take oil with them". As illustrated by Figures $2 \mathrm{a}$ and $2 \mathrm{~b}$, the systematic deterioration of WTI prices, started on July 2008, significantly accelerated because of COVID-19. 
Figure 2a: Weekly Cushing, OKWTI Spot Price FOB (2000-2020)

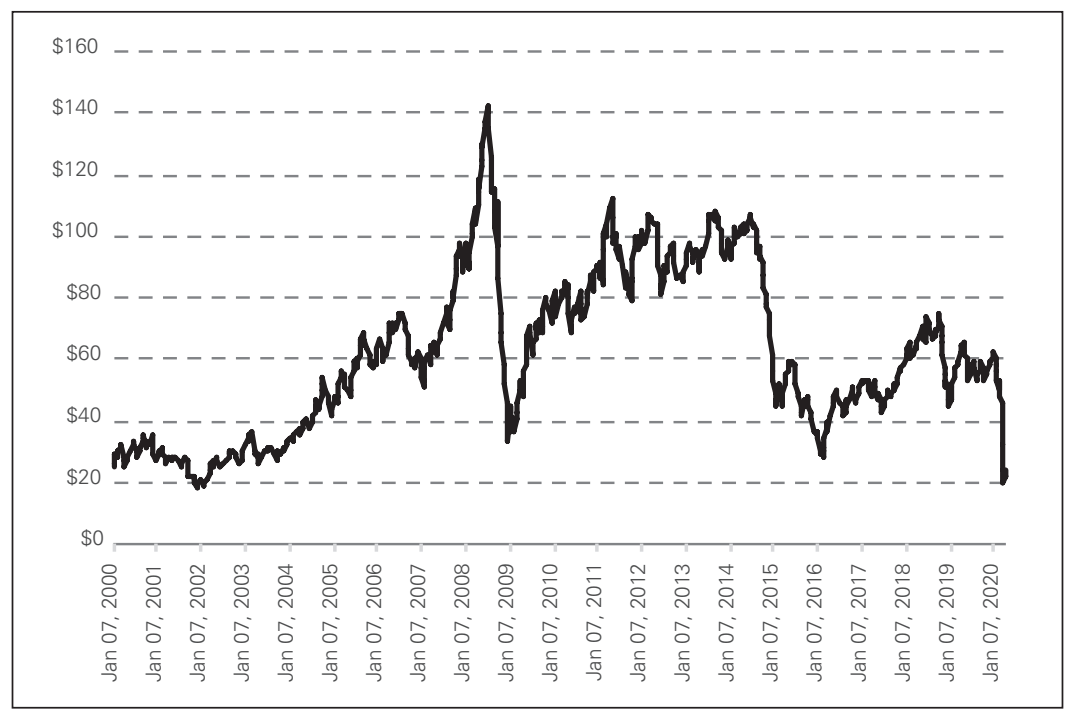

Source: Thomson Reuters. Available: http://tonto.eia.gov/dnav/pet/hist/LeafHandler.ashx? $n=$ PET\&S=RWTC\&f $=W$

Figure 2b: Weekly Cushing, OKWTI Spot Price FOB (2019-2020)

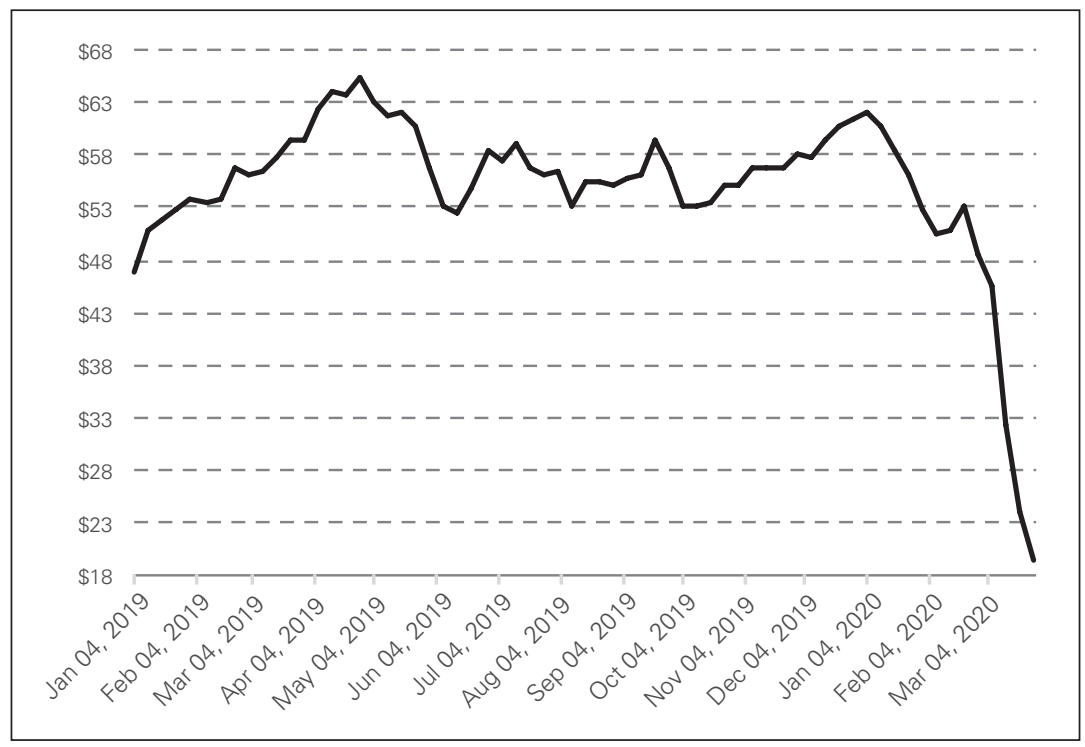

Source: Thomson Reuters. Available: http://tonto.eia.gov/dnav/pet/hist/LeafHandler.ashx? $n=$ PET\& $s=R W T C \& f=W$ 
The LAC economies that suffer the most are the ones which exportations are mainly oil. So, according to Table 3, the South American worst-off economies are Venezuela, Ecuador, and Colombia - Bolivia and Peru exports included in the fuels and mining products' classification are mainly mining. Indeed, the share of fuel and mining products in the total exports is over $90 \%$ in Venezuela, over $50 \%$ in Colombia and over $40 \%$ in Ecuador. Mexico, Brazil, and Argentina are also oil producers, but its public finances do not depend on oil's sale. Moreover, some Central American economies, as Jamaica and Suriname, are highly impacted by the collapse of oil prices. These countries face an important liquidity shortage so needing external financing sources to face the COVID-19 sanitary emergency.

\begin{tabular}{lccc}
\multicolumn{3}{c}{ Table 3: Share of fuels and mining products in the total exports by LAC country } \\
\hline & 2016 & 2017 & 2018 \\
\hline Argentina & $5 \%$ & $5 \%$ & $5 \%$ \\
Bolivia & $68 \%$ & $74 \%$ & $73 \%$ \\
Brazil & $15 \%$ & $18 \%$ & $21 \%$ \\
Colombia & $45 \%$ & $52 \%$ & $56 \%$ \\
Costa Rica & $1 \%$ & $2 \%$ & $1 \%$ \\
Dominican Republic & $9 \%$ & $10 \%$ & $10 \%$ \\
Ecuador & $35 \%$ & $39 \%$ & $43 \%$ \\
Guatemala & $8 \%$ & $6 \%$ & $5 \%$ \\
Guyana & $12 \%$ & $10 \%$ & $17 \%$ \\
Jamaica & $57 \%$ & $62 \%$ & $71 \%$ \\
Mexico & $4 \%$ & $4 \%$ & $5 \%$ \\
Paraguay & $25 \%$ & $24 \%$ & $23 \%$ \\
Peru & $57 \%$ & $62 \%$ & $61 \%$ \\
Suriname & $60 \%$ & $69 \%$ & $60 \%$ \\
Trinidad and Tobago & $32 \%$ & $32 \%$ & $32 \%$ \\
Venezuela & $95 \%$ & $96 \%$ & $97 \%$ \\
\hline
\end{tabular}

Source: World Trade Organization (Product group code: SI3_AGG-MI).

The LAC countries vulnerability to the COVID-19 shock is also reflected by its external debt patterns. Besides its high dependency to falling commodity prices, some LAC countries are highly indebted so that they have troubles to find financing sources to face a negative liquidity shock. LAC economics debt pattern can be analyzed through the Emerging Markets Bonds Index (EMBI) evolution. The EMBI is calculated based on the behavior of the external debt issued by each country. The less certainty that the country will honor its obligations, the higher the country's EMBI will be, and vice versa. Moreover, the EMBI is used as a spread among the interest rates paid by the bonds denominated in dollars, issued by underdeveloped countries, and the Treasury Bonds of the United States, considered "risk-free". So, the higher the EMBI the higher the cost of indebtedness for a country. Figures 3a and $3 \mathrm{~b}$ illustrates the time evolution of the LAC economies' EMBI from 2010 to 2020. Three patterns stand out: Venezuelan, Ecuadorian, and Argentinian. Venezu- 
Figure 3a: JPMorgan Emerging Market Bond Index (EMBI) from 2010 to 2020, LAC countries

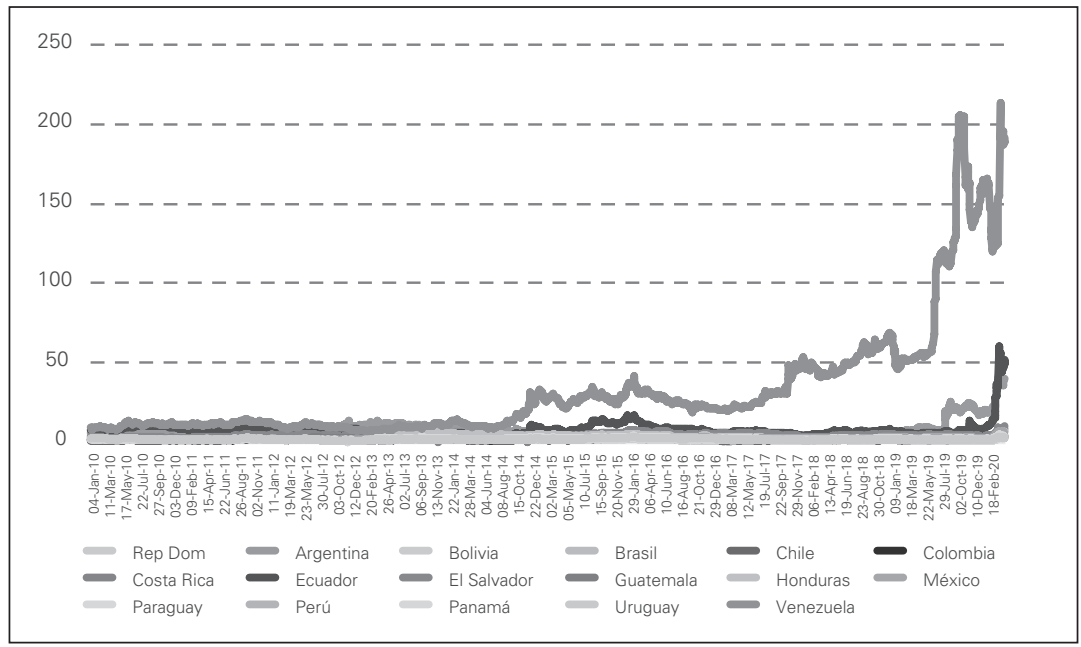

Source: JPMorgan Data (https://www.jpmorgan.com).

Figure 3b: JPMorgan Emerging Market Bond Index (EMBI) since March 2019, LAC ccountries

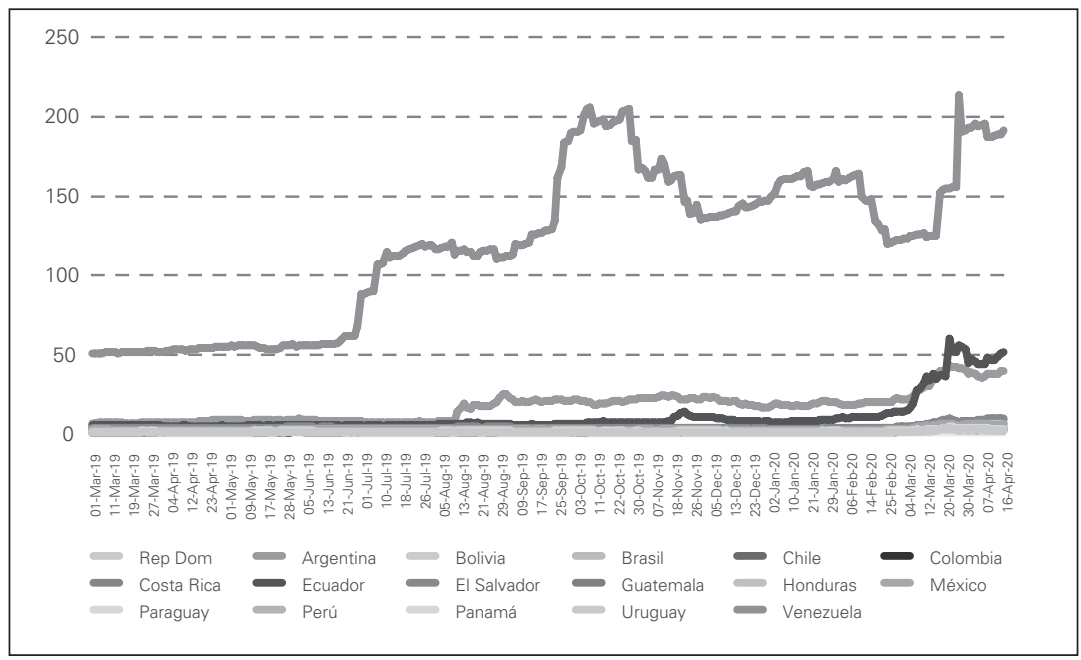

Source: JPMorgan Data (https://www.jpmorgan.com).

elan economic situation is unique, its economic collapse started long before the COVID-19's shock. However, as for all countries, EMBI has increased quicker during 2020. Ecuadorian economy is also interestingly vulnerable, Ecuador is not only a highly indebted country which public finances dangerously depend on oil 
prices but also Ecuador is a formally dollarized country which internal liquidity crucially depend on dollar receipts reduced by the COVID-19 shock. Meanwhile, Argentinian debt is the largest of all Latin America exceeding the US\$ 300.000 millions of dollars. Table 4 reports data on external debt stocks, as percentage of countries' gross national income (GNI), provided by the World Bank. Up to 2018, Argentina's debt represented the $56 \%$ of its GNI while Ecuadorian one represented almost the 43\%. Venezuela stopped to report data to the World Bank since 2015 .

As evidenced by Table 4, some LAC economies were already highly indebted before the COVID-19 shock. With the pandemic stopping the economic activity and requiring financing for the implemented health policies, LAC countries debt is risky rising. Moreover, because of the incertitude about the duration of the COVID-19 originated severe recession, global stock markets significantly fell causing financial capital runs away from risky markets looking for a save heaven. The consequence for the LAC region is that capitals leave the region causing national currencies to lost value against the US dollar. As illustrated by Figure 4, during the 2010-2019 period, Brazil, Chile, Mexico, Argentina, Peru, and Colombia's nation-

Table 4: External debt stocks (\% of GNI) by LAC country

\begin{tabular}{|c|c|c|c|c|c|c|c|c|c|}
\hline Country & 2010 & 2011 & 2012 & 2013 & 2014 & 2015 & 2016 & 2017 & 2018 \\
\hline Argentina & 30.9 & 27.7 & 26.2 & 27.7 & 29.7 & 30.3 & 34.6 & 37.8 & 56.1 \\
\hline Bolivia & 30.7 & 27.1 & 26.0 & 28.3 & 28.4 & 31.0 & 33.0 & 35.6 & 33.8 \\
\hline Brazil & 16.4 & 15.9 & 18.3 & 19.8 & 23.1 & 30.8 & 30.9 & 26.9 & 30.3 \\
\hline Colombia & 23.3 & 23.9 & 22.3 & 25.3 & 28.5 & 39.6 & 43.6 & 41.6 & 42.3 \\
\hline Costa Rica & 22.6 & 25.2 & 31.8 & 35.8 & 40.7 & 45.1 & 46.8 & 46.4 & 49.0 \\
\hline Dominica & 56.1 & 57.2 & 65.2 & 63.5 & 60.8 & 60.5 & 53.0 & 60.9 & 55.3 \\
\hline Ecuador & 22.4 & 20.7 & 18.8 & 20.4 & 25.0 & 29.1 & 36.1 & 40.3 & 42.6 \\
\hline Guatemala & 37.4 & 35.3 & 31.2 & 33.1 & 34.0 & 32.7 & 32.0 & 30.9 & 29.0 \\
\hline Guyana & 62.3 & 78.2 & 69.0 & 77.8 & 76.8 & 51.6 & 46.9 & 44.3 & 44.6 \\
\hline Honduras & 26.6 & 26.5 & 29.6 & 40.2 & 40.8 & 39.1 & 37.9 & 41.4 & 43.7 \\
\hline Haiti & 14.4 & 10.3 & 14.6 & 18.5 & 22.1 & 23.9 & 27.0 & 25.6 & 22.8 \\
\hline Mexico & 23.5 & 25.1 & 29.7 & 32.8 & 34.5 & 37.4 & 40.2 & 39.1 & 38.0 \\
\hline Peru & 30.8 & 28.3 & 34.1 & 33.3 & 35.4 & 36.7 & 37.8 & 33.6 & 31.3 \\
\hline Paraguay & 61.3 & 47.9 & 50.4 & 42.4 & 42.4 & 46.3 & 46.9 & 42.1 & 39.9 \\
\hline Venezuela & 30.1 & 44.1 & 41.0 & 43.1 & 33.9 & & & & \\
\hline
\end{tabular}

Source: The World Bank Data. Available information up to April 2020.

Indicator code: DT.DOD.DECT.GN.ZS. 
al currencies systematically appreciate. Such a 2010-2019 tendency reinforces because of the COVID-19 shock. Indeed, in the earlies 2020, the Latin American currencies plummet against the dollar: up to April 24th, 2020, in the Forex market a US dollar costed 5.61 Brazilian Reals, 858.70 Chilean pesos, 24.99 Mexican pesos, 66.35 Argentinian pesos, 4040.50 Colombian pesos, and 3.38 Peruvian Sols. So far, for these economies, the 2020 registers the biggest depreciation observed since 2000. The Ecuadorian case is worth noting, the US dollar appreciation against the local currencies of all its neighboring countries harms the already slowed down international commerce, and so, crucially reduces the internal Ecuadorian liquidity. This is the macroeconomic panorama that LAC countries face when caught by the COVID-19 shock. The extent to which they can react and implement economic policies is review next.

Figure 4: Exchange Rates evolution from 1990 to 2019 (national currency units/US dollar)

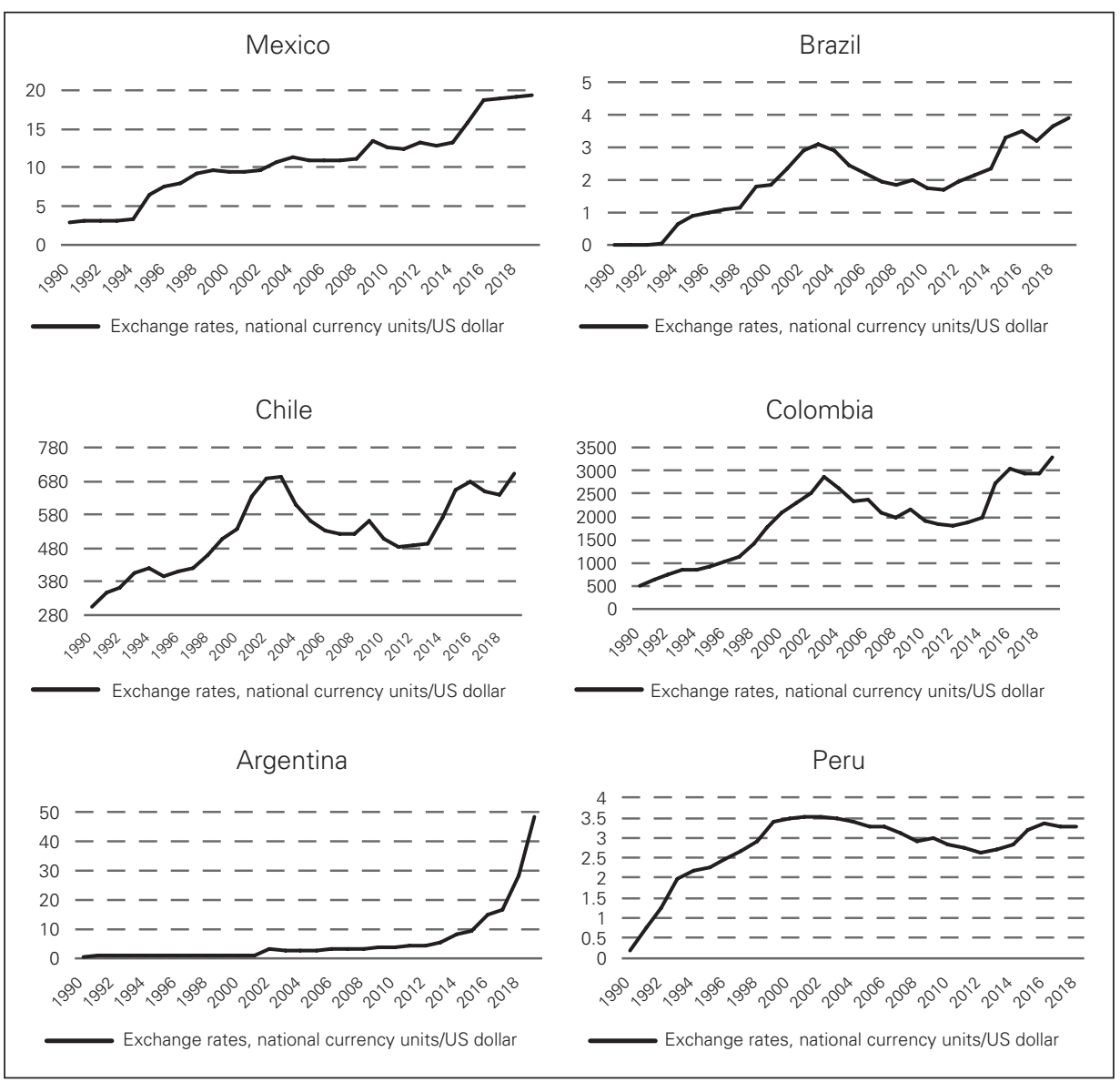

Source: OECD National Accounts Statistics: PPPs and exchange rates. 


\section{LAC countries' potential for reaction to face the economic recession}

Theoretically, an economy facing a recessive shock should react by using economic policy, basically, monetary, and fiscal policies, for increasing aggregate demand so that the economy reactivates (countercyclical policies). The problem with COVID-19 shock is that economy cannot be reactivated during the containment phase of the pandemic, so, the best option is to limit the downfall. Indeed, admitting that containment is necessary is to admit that recession is unavoidable: "in the short run, flattening the infection curve inevitably steepens the macroeconomic recession curve" (Gourinchas, 2020). And, as the longer the containment measures the deeper the economic recession (Atkeson, 2020; McKibbin \& Fernando, 2020), economic policy makers face a difficult choice.

Regardless the duration of the containment phase, there are some public policies which application has been commonly recognized as essential: (i) more spend on public health, (ii) economic compensations for people which income have reduced or disappeared (new unemployed people, people working on informal activities, etc.), (iii) economic aid for stopped businesses to survive the lockdown. These measures imply not only fiscal tools as increasing public spending or allowing tax deferrals, but also and monetary measures such as lowering policy rates or increase base money. Moreover, and specially in LAC, some unconventional measures have been adopted such as the exceptional allowance for households and firms to differ the payment of renting and utility bills.

On the fiscal side, even if LAC economies' public finances are fragile and despite their reputation of fiscal indiscipline (Santiso, 2011; Webb, 2004) and poor tax collection culture (Martner \& Tromben, 2003), some countries, as Peru, received the COVID-19 outbreak in better fiscal conditions and were able to implement significant fiscal stimulus packages. In fact, according to The World Bank (2020), in terms of GDP percentage, the Peruvian is the highest fiscal stimulus of all LAC countries (7\%) followed by the Chilean (almost 6\%), the Brazilian (almost $6 \%$ ), the Panamanian (3\%) and the Paraguayan and Guatemalan. The rest of LAC countries' fiscal stimulus are around $1 \%$. Of course, the size of fiscal stimulus depends on fiscal space which limits the countries capacity of reaction. Crucial cases are the ones of Venezuela and Ecuador which fiscal spaces are dangerously thin because of both very low oil prices (Figures $2 \mathrm{a}$ and $2 \mathrm{~b}$ ) and high external debt service (Table 4). The alternative financing sources are international organisms as the International Monetary Fund and the World Bank which have offered to lend millions of dollars for supporting the COVID-19 crisis (BBC, 2020c).

On the monetary side, the biggest issue for LAC countries is liquidity. As reported by The World Bank (2020), the COVID-19 shock implies strong short-term capital outflows from LAC countries: the capital outflows are even larger than those caused by the 2008 Global Financial Crisis or the global oil glut that started in 2014. Such a sudden stop increases risks for both the financial sector and the foreign exchange market so requiring assertive policy. It is worth noting that capi- 
tal outflows are particularly harming for the dollarized Ecuadorian economy which Central Bank cannot print money to inject liquidity.

So, the macroeconomic effects of COVID-19 shock for LAC countries are very similar for all the economies of the region but they magnitude is highly dependent on the pre-COVID-19 economic condition of each LAC country as well as to their economic structure. The most vulnerable LAC economies appears to be Venezuela, Ecuador, and Argentina.

\section{Microeconomic perspectives}

The economic relationships among economic agents (producer and consumer) make the different markets take place. However, consumers do not necessarily know how products arrive to a shop. In fact, almost every product that arrives to the consumer should pass for a distribution system, which means that several companies are involved in the process. Therefore, the relationships among companies located at different levels of the distribution chain, such as suppliers and distributors or wholesalers and retailers, are usually invisible to consumers' eyes. These relationships could involve different economic sectors, and all the companies face several risks related to the economic activity.

Indeed, every company must face the risks of failure due economic activity. Literature does not agree about how particular conditions of firms prevent failure or help to growth. Authors like (Kosová \& Lafontaine, 2010) emphasize that in order to survive, manufacturing firms are continuously modifying their products. In fact, authors find evidence that age and size have negative impact on growth. However, age has positive influence on survival.

In this context, literature disagrees about the reasons why firms prevent failure. However, firm' characteristics are not the only factors to consider. In fact, the environment where firms develop their activities as well as other macroeconomic conditions like economy, technology and infrastructure levels, and institutional factors, influence in the probability of survival. Even the organizational choice would be a way to adapt to the institutional environment. In this context, firms should have institutional knowledge of the country in order to locate a firm. Institutional knowledge is related to the information about government structures in specific countries, i.e., their rules, regulations and norms (Eriksson et al., 2000). COVID-19 has changed every economic environment around the world. Therefore, the probability of failure could be severely increased due to economic conditions. In fact, authors like (Buddelmeyer, Jensen, \& Webster, 2006) and (Ejermo \& Xiao, 2014) found empirical evidence that in the case of entrepreneurs, the failure probability increases on recession times. In regular times, this situation could be explained through business cycle theory. Business cycle theory tries to explain why aggregate variables go under repeated fluctuations on a similar trend (Lucas, 1976).

On the other hand, Schumpeterian arguments recognize the importance of innovation to prevent failure. In fact, entrepreneurs' purpose is to convert the invention into an innovation. It is highlighted, that small and medium-sized companies 
are becoming more important in defining alternative strategies and tactics for creating new market niches (Guichardaz \& Pénin, 2019). Therefore, firms with a good innovation capacity will have a greater chance of survival in normal conditions. Notwithstanding, survival in this COVID-19 context seems to be more linked to the economic sector to which the firm belongs, despite that small and medium-sized companies have been doing innovation. In these sense, the COVID-19 situation has shown, that depending on the economic sector firms could: (i) continue to produce or sell their goods, (ii) reduce or increase their production, (iii) adapt or change their goods to prevent failure, and (iv) stop their economics activities due to lockdown, to contain the spread of the virus 19 . Next, we will make a general description of how this pandemic has influenced the economic activity of some economic sectors.

\section{Winners}

Undoubtedly, companies are challenging to reinvent themselves to remain in the market. This can be illustrated with the Golden Sweet Spirit company from Ecuador. The company exports were mainly USA. However, it fell $70 \%$ due to lockdown. This company focus now in local Ecuadorian market. Because their principal market was USA, they must do a lot of effort to achieve local Ecuadorian market. In fact, their product has been highly accepted with $70 \%$ of their production (previously 1\%). The rest is used to create industrialized food. Thanks to this, Golden Sweet Spirit remains open and they even hired more persons to help them to expand (Líderes, 2020).

Most of the companies in food sectors, without restaurants, have been able to remain open to ensure food for population. Therefore, the effects of COVID-19 have been less important compared to other economic sectors. However, in Latin America distribution channels that take into account home delivery services to reach the consumer have not been widely used. One of the reasons for that, is the lack payment using electronic systems. Most people in Latin America do not have these facilities, as well as a good internet connection. Notwithstanding, consistent with Schumpeter's arguments, small and medium enterprises have had to innovate to get closer to the consumer quickly. This has been possible through the quickly development of delivery services by using mobile applications or telephone calls, in which is allowed the cash payments. This has allowed many companies to survive and in fact, some of them have changed the line of business. For example, bars, restaurants, and coffee shops are now food retailer's door-to-door. Another observed adaptation is the use of food packages with basic foods to accelerate their distribution. The same is true for large distributors such as amazon or supermarkets (like Wal-Mart), who have seen their wealth increase. In the same sense, communication platforms such as Facebook or zoom have seen their users increase, and therefore their wealth. 


\section{Uncertain future}

Restaurants, hotels, and airlines are among the sectors hardest hit by the pandemic, but self-employed and informal workers have also seen their incomes decline or disappear.

In this context, one of the industries most affected during this pandemic, is without doubt tourism. However, the World Tourism Organization (2020) signals that is early to evaluate the impact of COVID-19 in this sector, due to the pandemic is still ongoing. WTO based on SARS consequences, argue that international tourist arrivals could decrease by $20 \%-30 \%$, compared to the growth expected in January 2020. Another example of the impact on this sector is Ecuador, where tourism accounted 2.2\% of GDP in 2019. Although tourism sector is not one of the most important in Ecuador's economy, the Tourism Minister points out that if the industry has a 30-day stoppage, the losses could be close to $\$ 150$ million. For 60-day stoppage the losses could reach $\$ 345$ million and with 90 days' stoppage could add up to $\$ 540$ million. In addition, of the major losses in the tourism sector, there is others economic sector that are indirect part of the tourism, such as airlines, restaurants, internal transportation, among others. In fact, airlines have canceled flights due lockdown, to contain the propagation of COVID-19, imposed by some countries. The objective of these measures is to prevent the spread of the virus through border closures. Therefore, airlines companies have almost stopped their flights, the arrival of tourist has been greatly reduced, as already mentioned. This comes with a low or no hotel occupancy, the same as for restaurants and all other economic sectors related to the tourism sector. Therefore, countries dependent on tourism will face serious deficits in their economies.

\section{Change in consumer preferences}

Consumers are heterogeneous in their preferences of goods. The ideal product on the market differ from a customer to other due to personal preference such modern design or more traditional design. In this context, consumers buy what seems closest to what they understand by ideal. However, this argument supposes that there are many products to choose in the market. In the COVID-19 context, is not necessary the case. Consumers had to change regular consumer habits, first they are not allowed to buy some products such as clothes since shops remains closed. Second, they buy principally food. Indeed, both supermarkets and home delivery services have reported a huge increase in demand, while consumers buy large quantities of products such as toilet paper, rice, and orange due to the increase in the pandemic. Indeed, crowd of people outside the supermarkets are common scenes nowadays. In some cases, clients must wait hours before to buy. In this context, COVID-19 could have changed consumer habits and therefore, their preferences have been quickly adjusted to this context.

This preference is also adjusted by the income of the family. In fact, labor market has received a hard impact due to the reduction of economic activities in 
most of the economic sectors, amid the emergency due to the COVID-19 pandemic. For instance, the National Institute of Statistics and Censuses of Ecuador (INEC) reported 3.4 million people with adequate / full employment: 1.4 million in underemployment and 311134 unemployed citizens, in December 2019. Adaptations in the labor market have been allowed such as: telework, modification or suspension of work. However, in LAC countries a great number of people is in the informal sector. These people depend on their daily economic activities, which are not allowed in quarantine and, in most of the cases, they have no access to the social security and health system. Thus, their survival is not only depending whether getting COVID-19, but also by the access of basics resources needed to survive. Therefore, vulnerable people are not only concern by COVID-19, they are also concern by the temporary closure of companies/factories and the access of goods for their daily subsistence. In fact, in Latin America about $50 \%$ of workers are in the informal sector and for them, the restriction on going out is economically devastating.

\section{Social implications}

Given the economic, political, and even historical heterogeneity of LAC countries, it is expected that social COVID-19 implications may be different in each of them. Nevertheless, there are aspects that can be transversal for the entire region. For instance, the Venezuelan exodus, which mainly has as destination LAC countries such as Brazil, Colombia, Ecuador and Peru (Díaz-Sánchez et a., 2020) may increase the contagion velocity intra-region. As a matter of fact, the Venezuelan exodus has been already related to other infectious spreads such as malaria or measles (Suárez et al., 2019). In the same way, border closures, a common instrument to stop COVID-19 expansion, may accelerate Venezuelan irregular entries in countries of the region as well as their vulnerability at their destination. On the other way around, newspaper reports (EL COMERCIO, 2020; EL UNIVERSO, 2020) suggest that Venezuelans, which usually settled in high populated cities such as Guayaquil (Ecuador) and enrolled in the informal labor market, are moving back to Venezuela due to lockdowns in neighboring countries that do not allow them to continue with their economic activities.

In addition, it is also expected that the flow of remittances from developed economies to the region would experience a significant decrease in the short-run. For instance, the $88 \%$ of remittances that arrive to Ecuador come from USA, Spain and Italy, which are 3 of most affected countries by COVID-19.

Further, COVID-19 represents a challenge for healthcare systems of the region which are already considered fragile (The Lancet, 2019)). Actually, fragmentation and segmentation are ongoing challenges for most of these vulnerable systems (Rodriguez-Morales et al., 2020). Even Brazil, which may be the most developed economy of the region, has a modest investment in public health $-3.8 \%$ of the GDP - (see Table 5) compared to UK, Spain or France that invest 7.9, 8 and 10\% of their GDP in public health, respectively. 


\begin{tabular}{|c|c|c|c|}
\hline Country & $\begin{array}{l}\text { Health expenditure } \\
\text { per capita (US\$ PPP) }\end{array}$ & $\begin{array}{l}\text { Public expenditure } \\
\text { (\% GDP) }\end{array}$ & $\begin{array}{c}\text { Private expenditure } \\
\text { (\% GDP) }\end{array}$ \\
\hline Cuba & 2,486 & 10.6 & 0.5 \\
\hline Chile & 2,229 & 4.9 & 3.2 \\
\hline Uruguay & 2,102 & 6.4 & 2.8 \\
\hline Argentina & 1,917 & 4.9 & 1.9 \\
\hline Panama & 1,795 & 4.3 & 2.6 \\
\hline Brazil & 1,472 & 3.8 & 5.0 \\
\hline Costa Rica & 1,237 & 6.2 & 2.0 \\
\hline Colombia & 1,039 & 4.1 & 1.8 \\
\hline Mexico & 1,036 & 3.1 & 2.8 \\
\hline Dominican Rep. & 986 & 2.5 & 3.3 \\
\hline Ecuador & 959 & 4.2 & 4.3 \\
\hline Paraguay & 867 & 4.2 & 3.6 \\
\hline Peru & 681 & 3.2 & 2.0 \\
\hline EI Salvador & 583 & 4.4 & 2.5 \\
\hline Nicaragua & 506 & 4.4 & 3.0 \\
\hline Guatemala & 475 & 1.8 & 3.8 \\
\hline Bolivia & 462 & 4.4 & 1.9 \\
\hline Honduras & 395 & 2.9 & 4.1 \\
\hline Haiti & 146 & 0.7 & 2.8 \\
\hline Venezuela, RB & 141 & 1.5 & 1.7 \\
\hline
\end{tabular}

Source: Information adapted and improved from BBC (2020).

In the same line, lockdowns and mandatory quarantines adopted by the majority of LAC countries as anti COVID-19 spread actions may release a latent social problem in the region: gender violence. As a matter of fact, studies indicate that up to $40 \%$ of women in the region have been victims of violence at some point during their lives (Alvarez \& Birkbeck, 2010). For instance, these authors point out that Guatemala had the world's highest rate with 123 femicides per one million women followed by Colombia (70), El Salvador (66), Bolivia (43), Dominican Republic (37), and Mexico (24) in 2003. Considering that violence perpetrators usually are 
those ones in the household environment (Gekoski, Davidson, \& Horvath, 2016; Tener, Tarshish, \& Turgeman, 2017), being trapped with the perpetrator during quarantines clearly increases the chances of suffer gender violence with no possibilities to scape.

In addition, the insufficient adequate dwelling in the region as well as household overcrowding can serve as a breeding ground for conflict and detrimental aspects of health at household level in extended periods of quarantine. Actually, according to Royuela, Díaz-Sánchez, \& Romaní (2019), overcrowding is determinant of well-being and significant as a deterrence factor in personal development. For instance children in overcrowded households have a higher probability of getting sick (Baldassare, Edwards, Fuller, Vorakitphokatorn, \& Sermsri, 1995); in addition, a lack of privacy results in stress, and generates behavioral problems for all household members (Evans, Lepore, Shejwal, \& Palsane, 1998). Therefore, it is expected that extended quarantines in LAC countries may have negative physical and psychological consequences on dwellers, especially children.

\section{CONCLUSION AND DISCUSSION}

Humanity have overcome pandemics such as Plague of Justinian, Black Death, Smallpox, Great Plague of Marseille, Spanish Flu, SARS, which killed million people worldwide. We also stopped potential pandemics like the Ebola virus through proactive public health initiatives, through the development of drugs and vaccines that now keep people alive.

In 2020, the humanity is facing a new pandemic caused by the so-called SARSCoV-2 virus (the COVID-19's pandemic). To face this situation, almost all countries in the world agreed to contain the SARS-CoV-2 expansion through quarantine and social distancing. In such a context, the COVID-19's pandemic necessarily implies a global economic recession because of the sudden stop of several economic activities as tourism, spectacles, trade of some goods and services, among others.

At a macroeconomic level, the COVID-19 shock causes both aggregate supply and aggregate demand to reduce so plunging the world into a global recession. According to the World Bank and the IMF, the global recession caused by the COVID-19 pandemic will be far greater than that caused by the global financial crisis of 2008-2009 and even comparable to the Great Depression of 1929. LAC economies are particularly vulnerable to the COVID-19 shock because (i) they are characterized to be commodities producers which price have significantly fall, (ii) they are highly indebted, (iii) they are considered as risky countries by financial markets so financial capital are running away from the LAC region, (iv) their national currencies are losing value against the US dollar, (v) their public finances are fragile and (vi) some LAC countries central banks are suffering from serious liquidity issues.

As most countries in the world, the LAC governments are facing the COVID-19 
shock by implementing essential public policies (increasing public health spending, implementing economic compensations for people which income have reduced or disappeared and for stopped businesses) which financing is worsening their already thin fiscal spaces and increasing their already high debt levels. The COVID-19 shock is causing a second Great Depression or "Great Quarantine" which deepness is still to be seen.

The microeconomic impact for LAC countries could be divided into consequences for firms and consumers. In terms of firms, COVID-19 has had different effects on firms. Some enterprises would adapt to remain in the market or even growth; in contrast, others would leave the market in the short-run. As already mentioned, several economic sectors are being severely affected especially travel and tourism. However, it is expected that business travel could help to recover this sector in the long-run. For the consumers, the impact of this sanitary crisis is related to the change in their preferences, due to restrictions in buying or the change in their income. In addition of tourism, we also believe that migration flows into the region will be affected, specially Venezuelans. In the same line, remittances from developing countries to the region will decrease. Finally, we also consider that household members' relations will be affected by extended quarantines given the overcrowding and gender violence conditions that prevalence in LAC.

Finally, the world has changed with every pandemic. In this context, we will need to learn the correct lessons from the coronavirus crisis, from the inequities in our healthcare system, to the national manufacturing of critical items such as masks by strengthening of small business.

\section{REFERENCES}

Alvarez, G., \& Birkbeck, M. (2010). Gender: Violence Against Women. Retrieved from http://www. unifem.org/gender_issues/violence_against_women/

Atkeson, A. (2020). What Will Be the Economic Impact of COVID-19 in the US? Rough Estimates of Disease Scenarios. In NBER Working Paper Series.

Baldassare, M., Edwards, J. N., Fuller, T. D., Vorakitphokatorn, S., \& Sermsri, S. (1995). Household Crowding and its Consequences. Contemporary Sociology, 24(5), 652. https://doi. org $/ 10.2307 / 2077377$

BBC. (2020a). Coronavirus: los gráficos y mapas que muestran el impresionante impacto económico de la pandemia - BBC News Mundo. Retrieved May 14, 2020, from https://www.bbc.com/mundo/ noticias- 52080594

BBC. (2020b). El coronavirus en América Latina: así avanza la pandemia de covid-19 en la región BBC News Mundo. Retrieved April 13, 2020, from https://www.bbc.com/mundo/noticias-america-latina-52131238

BBC. (2020c, April). Coronavirus: con cuánto dinero cuentan el FMI y el Banco Mundial (y qué tanto pueden ayudar a los países más golpeados por la pandemia).

Buddelmeyer, H., Jensen, P. H., \& Webster, E. (2006). Innovation and the Determinants of Firm Survival. Institute for the Study of Labor (IZA), (2386), 27.

Chen, W. H., Strych, U., Hotez, P. J., \& Bottazzi, M. E. (2020). The SARS-CoV-2 Vaccine Pipeline: an Overview. Current Tropical Medicine Reports, 1-4. https://doi.org/10.1007/s40475-020-00201-6 
Conseil de l'Union européenne. (n.d.). Épidémie de coronavirus COVID-19 et réaction de l'UE - Consilium. Retrieved May 14, 2020, from 2020 website: https://www.consilium.europa.eu/fr/policies/ covid-19-coronavirus-outbreak-and-the-eu-s-response/

ECLAC. (2020). América Latina y el Caribe ante la pandemia del COVID-19: Efectos económicos y sociales.

Ejermo, O., \& Xiao, J. (2014). Entrepreneurship and survival over the business cycle: How do new technology-based firms differ? Small Business Economics, 43(2), 411-426. https://doi.org/10.1007/ s11187-014-9543-y

Eichelberger, L. (2007). SARS and New York's Chinatown: The politics of risk and blame during an epidemic of fear. Social Science and Medicine, 65(6), 1284-1295. https://doi.org/10.1016/j.socscimed.2007.04.02

EL COMERCIO. (2020). Venezolanos abandonan a pie Guayaquil en medio de emergencia sanitaria; hay 22 contagiados por covid-19 en Ecuador I El Comercio. Retrieved from https://www.elcomercio.com/actualidad/venezolanos-abandonan-guayaquil-pandemia-crisis.html? fbclid=Iw AR1LF_mEitZNhTeUjM3F4JH9URR8Yq3RQLfnxPjjwbwgMJs4d8Hs1GAqDW4

EL UNIVERSO. (2020). Venezolanos abandonan Guayaquil, caminan a Quito y buscan salir del país por crisis económica desatada por el coronavirus | Ecuador | Noticias | El Universo. Retrieved from https:/www.eluniverso.com/noticias/2020/04/21/nota/7819245/venezolanos-abandonan-guayaquil-caminan-quito-buscan-salir-pais?fbclid=IwAR1CJmXTGRyuWru1QHJw_pnBbdqOX qWBl_6eH9GD1t2nY3CM3akMGJUmxMo

Evans, G. W., Lepore, S. J., Shejwal, B. R., \& Palsane, M. N. (1998). Chronic Residential Crowding and Children's Well-Being: An Ecological Perspective. Child Development, 69(6), 1514. https://doi. org/10.2307/1132129

Gallagher, K., \& Porzecanski, R. (2009). China and the Latin America Commodities Boom: A Critical Assessment.

Gekoski, A., Davidson, J. C., \& Horvath, M. A. H. (2016). The prevalence, nature, and impact of intrafamilial child sexual abuse: findings from a rapid evidence assessment. Journal of Criminological Research, Policy and Practice, Vol. 2, pp. 231-243. https://doi.org/10.1108/JCRPP-05-2016-0008

Gourinchas, P.-O. (2020, March). Flatten the Curve of Infection and the Curve of Recession at the Same Time.

Guichardaz, R., \& Pénin, J. (2019). Why was Schumpeter not more concerned with patents? Journal of Evolutionary Economics, 29(4), 1361-1369. https://doi.org/10.1007/s00191-019-00633-y

Kosová, R., \& Lafontaine, F. (2010). Survival and growth in retail and service industries: Evidence from franchised chains. Journal of Industrial Economics, 58(3), 542-578. https://doi.org/10.1111/ j.1467-6451.2010.00431.x

Lee, J.-W., \& McKibbin, W. J. (2004). Globalization and Disease: The Case of SARS. Asian Economic Papers, 3(1), 113-131. https://doi.org/10.1162/1535351041747932

LÍDERES. (2020). El desafío de las empresas está en reinventarse para seguir activas I Revista Líderes. Retrieved from https://www.revistalideres.ec/lideres/desafio-empresas-reinventarse-seguir-activas. html?fbclid=IwAR1n7L37Rh4Ay80Gs101IuJ5JnHwIaO7lsG9jAd0viQq5VbXePPgtcMhxwo

Lucas, R. (1976). Understanding business cycles. Kiel Conference on Growth without Inflation, 13(December 1966), 258-283.

Martner, R., \& Tromben, V. (2003). Tax Reforms and Fiscal Stabilisation in Latin American Countries. Tax Policy Conference, 569.

McKibbin, W. J., \& Fernando, R. (2020). The Global Macroeconomic Impacts of COVID-19: Seven Scenarios. In SSRN Electronic Journal. https://doi.org/10.2139/ssrn.3547729

Novel Coronavirus Pneumonia Emergency Response Epidemiology Team. (2020). [The epidemiological characteristics of an outbreak of 2019 novel coronavirus diseases (COVID-19) in China]. Zhonghua Liu Xing Bing Xue Za Zhi = Zhonghua Liuxingbingxue Zazhi, 41(2), 145-151. https://doi.org/10.3760/cma.j.issn.0254-6450.2020.02.003 
Prompetchara, E., Ketloy, C., \& Palaga, T. (2020). Immune responses in COVID-19 and potential vaccines: Lessons learned from SARS and MERS epidemic. Asian Pacific Journal of Allergy and Immunology, 38(1), 1-9. https://doi.org/10.12932/AP-200220-0772

Rodriguez-Morales, A. J., Gallego, V., Escalera-Antezana, J. P., Méndez, C. A., Zambrano, L. I., Franco-Paredes, C., ... Cimerman, S. (2020). COVID-19 in Latin America: The implications of the first confirmed case in Brazil. Travel Medicine and Infectious Disease, (xxxx). https://doi.org/10.1016/j. tmaid.2020.101613

Royuela, V., Díaz-Sánchez, J. P., \& Romaní, J. (2019). Migration effects on living standards of the left behind. The case of overcrowding levels in Ecuadorian households. Habitat International, 102030. https://doi.org/10.1016/J.HABITATINT.2019.102030

Santiso, C. (2011). Budget Institutions and Fiscal Responsibility: Parliaments and the Political Economy of the Budget Process. In SSRN Electronic Journal. https://doi.org/10.2139/ssrn.657663

Signoli, M. (2012). Reflections on crisis burials related to past plague epidemics. Clinical Microbiology and Infection, 18(3), 218-223. https://doi.org/10.1111/j.1469-0691.2012.03787.

Smith, R. D. (2006). Responding to global infectious disease outbreaks: Lessons from SARS on the role of risk perception, communication and management. Social Science and Medicine, 63(12), 3113-3123. https://doi.org/10.1016/j.socscimed.2006.08.004

Spyrou, M. A., Tukhbatova, R. I., Feldman, M., Drath, J., Kacki, S., Beltrán De Heredia, J., ... Krause, J. (2016). Historical Y. pestis Genomes Reveal the European Black Death as the Source of Ancient and Modern Plague Pandemics. Cell Host and Microbe, 19(6), 874-881. https://doi.org/10.1016/j. chom.2016.05.012

Tener, D., Tarshish, N., \& Turgeman, S. (2017). “Victim, Perpetrator, or Just My Brother?” Sibling Sexual Abuse in Large Families: A Child Advocacy Center Study. Journal of Interpersonal Violence, 886260517718831. https://doi.org/10.1177/0886260517718831

THE LANCET. (2019, November 30). The unfolding migrant crisis in Latin America. The Lancet, Vol. 394, p. 1966. https://doi.org/10.1016/S0140-6736(19)32934-4

The World Bank. (2020a). The Economy in the Time of Covid-19. In The Economy in the Time of Covid-19. https://doi.org/10.1596/978-1-4648-1570-6

The World Bank. (2020b). World Development Indicators I The World Bank. Retrieved April 13, 2020, from http://wdi.worldbank.org/tables

Webb, S. B. (2004). Fiscal responsibility laws for subnational discipline : The Latin American experience. In World Bank.

World Tourism Organization. (2020). International Tourism and covid-19 I UNWTO. Retrieved May 14, 2020, from https://www.unwto.org/international-tourism-and-covid-19

WHO, W. H. O. (2020a). WHO Director-General's opening remarks at the media briefing on COVID-19 - 9 March 2020.

Xu, Z., Shi, L., Zhang, J., Huang, L., Zhang, C., Liu Bsc, H., ... Dong, J. (2020). Case Report Pathological findings of COVID-19 associated with acute respiratory distress syndrome. https://doi. org/10.1016/S2213-2600(20)30076-X 


\section{Appendix}

Table A1: Adopted policies by LAC countries in COVID-19 context

\begin{tabular}{|c|c|c|c|}
\hline Country & Health policy & $\begin{array}{l}\text { Economic } \\
\text { Policy }\end{array}$ & Other policy \\
\hline Argentina & $\begin{array}{l}\text { Mandatory quarantine, suspension } \\
\text { of classes, closure of borders and } \\
\text { flight suspension. }\end{array}$ & & \\
\hline Bolivia & $\begin{array}{l}\text { Declaratory of sanitary emergency, } \\
\text { closure of borders and flight } \\
\text { suspension. }\end{array}$ & & $\begin{array}{l}\text { Government pays drink- } \\
\text { able water and electricity } \\
\text { bills for three months } \\
\text { for vulnerable population. } \\
\text { Moreover, the govern- } \\
\text { ment gave food for } 1.5 \mathrm{M} \\
\text { vulnerable families. }\end{array}$ \\
\hline Brazil & $\begin{array}{l}\text { Cancellation of massive events, } \\
\text { suspension of classes, reduction } \\
\text { of public transportation, prohibition } \\
\text { of cruisers, tables at restaurants at } \\
\text { minimum } 2 \text { meters of distance. }\end{array}$ & & \\
\hline Chile & $\begin{array}{l}\text { Declaratory of state of emergency } \\
\text { due to catastrophe, closure of } \\
\text { borders for people (no load), } \\
\text { suspension of classes, prohibition of } \\
\text { visits in geriatric centers, prohibition } \\
\text { of massive meetings. }\end{array}$ & & \\
\hline Colombia & $\begin{array}{l}\text { Declaratory of state of emergency, } \\
\text { closure of borders, cancellation } \\
\text { of flights, mandatory quarantine, } \\
\text { suspension of activities in schools, } \\
\text { restaurants and bars, and prohibition } \\
\text { of massive events. }\end{array}$ & $\begin{array}{l}\text { Reduction } \\
\text { of taxes } \\
\text { and credits } \\
\text { for tourism } \\
\text { and flight } \\
\text { industries. }\end{array}$ & \\
\hline Costa Rica & $\begin{array}{l}\text { Closure of schools, reduction of } \\
50 \% \text { of capacity of public spaces, } \\
\text { suspension of travels abroad } \\
\text { for public employees, closure of } \\
\text { theaters, casinos, bars and cinemas. }\end{array}$ & & \\
\hline Cuba & $\begin{array}{l}\text { Suspension of classes, restriction } \\
\text { of mobility among provinces, } \\
\text { suspension of public events. }\end{array}$ & & \\
\hline $\begin{array}{l}\text { Domini- } \\
\text { can Rep. }\end{array}$ & $\begin{array}{l}\text { Closure of borders, suspension of } \\
\text { classes, and suspension of flights. }\end{array}$ & & \\
\hline Ecuador & $\begin{array}{l}\text { Declaratory of state of exception, } \\
\text { mandatory quarantine, suspension } \\
\text { of most economic activities. }\end{array}$ & & $\begin{array}{l}\text { Cash transfer of } 60 \text { USD } \\
\text { for vulnerable population } \\
\text { for three months. }\end{array}$ \\
\hline
\end{tabular}




\section{Honduras Closure of borders, suspension of classes and massive events.}

Declaration of state of emergency,

Haiti closure of borders, closure of schools and churches

Soft measures: restriction of tourist between Mexico and USA, no

Mexico restrictions of flights, random revision of international passengers. Suspension of classes.

Nicaragua No measures at all.

Declaratory of state of national

Panama emergency. Suspension of flights, closure of business.

Peru Mandatory quarantine, closure of borders, suspension of classes,

Partial closure of land borders.

Paraguay Suspension of classes and massive events. Suspension of flights.

El

Salvador

Mandatory quarantine, suspension of classes, closure of borders and flight suspension.

Suspension of classes, suspension of flights, closure of borders.

Venezuela, Mandatory quarantine, suspension $\mathrm{RB}$
Free access to public web sites and 5 minutes per day calls and 50 text messages free for vulnerable population

Cash transfer of 105 USD for households in the informal sector of the labor market

Government established referential prices for alcohol, antibacterial gel, masks and gloves.

Government announced the postponement of payments of drinkable water, electricity, telephone, and internet, as well as credits.

Source: Newspapers Reports. 